\title{
Toxicity of some bioactive medicinal plant extracts to Asian army worm, Spodoptera litura
}

\section{Priyanka Bhatt", Nitin Thodsare and R. P. Srivastava}

Department of Entomology, College of Agriculture, G.B. Pant University of Agriculture and Technology, Pantnagar-263145 (Uttarakhand), INDIA

*Corresponding author. E-mail: priyangp30695@gmail.com

Received: November 20, 2013; Revised received: April 5, 2014; Accepted: April 20, 2014

\begin{abstract}
Comparative toxicity of Andrographis paniculata (leaves), Anethum graveolens (leaves), Azadirachta indica (fruits), Cassia fistula (seeds), Cuscuta reflexa (stem), Dendropthoe falcata (leaves), Lantana camara (leaves and fruits), Melia azedarach (leaves) and Vitex negundo ( stem) plant extracts against $2^{\text {nd }}$ days (first instar) and $6^{\text {th }}$ days(third instar) old larvae of Spodoptera litura was studied at 5 and $10 \mathrm{mg} / \mathrm{ml}$ concentration. $D$. falcata leaves $(98.58 \%)$ and $A$. indica fruits $=C$. reflexa $(85.72 \%)$ were most effective in reducing weight gain in $2^{\text {nd }}$ days old larvae at $5 \mathrm{mg} / \mathrm{ml}$ and at $10 \mathrm{mg} / \mathrm{ml}$, C. reflexa $(98.58)$ followed by C. fistula seeds and L.camara fruits(both $92.86 \%)$ were effective in retarding growth. L.camara fruit extract $(99.43$ and $99.93 \%)$ showed greater toxicity and reduced growth as compared to $A$. graveolens leaves $(76.16 \%$ ) at $5 \mathrm{mg} / \mathrm{ml}$. At $10 \mathrm{mg} / \mathrm{ml}$ L.camara $(99.94 \%)$ and $A$. paniculata $(89.54 \%)$ leaves exhibited reduction in weight gain over control against $6 \mathrm{~d}$ old larvae. All the medicinal plants showed varying degree of toxicity. D.falcata, A.indica and L.camara exhibited high larval mortality as compared to the other plant extracts.
\end{abstract}

Keywords: Botanicals, Medicinal plants, Mortality, Spodoptera litura, Toxicity

\section{INTRODUCTION}

Insect pest management is facing economic and ecological challenge worldwide due to the human and environmental hazards caused by majority of the synthetic pesticides (Rattan, 2010). The indiscriminate use of chemical pesticides has given rise to many well-known and serious problems, including genetic resistance of pest species, toxic residues in stored products, increasing costs of application, hazards from handling and environmental pollution (Rembold, 1994). Plants have evolved as a whole arsenal of defence strategies against herbivores, including the synthesis of a tremendous variety of chemical compounds. Chemical defence products may range from low molecular weight secondary metabolites, to peptides and proteins that are active against insects (Ibanez, 2012).The botanical insecticides are generally pest-specific and are relatively harmless to non-target organisms including man. They are also biodegradable and harmless to the environment. These natural products generally inhibit insect's development, behaviour and provoke precocious moulting and alter the growth regulating hormones to cause malformations, sterility or death in insects (Celis et al., 2008). Therefore the present investigation was conducted to compare the toxicity and growth regulatory properties of some plant extracts against $2^{\text {nd }}$ and $6^{\text {th }}$ day old larvae of Asian army worm Spodoptera litura.

\section{MATERIALS AND METHODS}

Preparation of methanol powders: The fresh plant parts viz. Andrographis paniculata (leaves), Anethum graveolens (leaves), Azadirachta indica (fruits), Cassia fistula (seeds), Cuscuta reflexa (stem), Dendropthoe falcata (leaves), Lantana camara (leaves and fruits), Melia azedarach (leaves) and Vitex negundo (stem) were washed in running tap water and dried in shade for a week. The dried plant samples were weighed and macerated in electric grinder into a fine paste, completely dipped in methanol in separate flasks, and kept at room temperature. After 3-4 days, the extract was filtered through Whatmann filter paper and centrifuged at 5000 rates per minute (rpm) for 10minutes. The supernatant was evaporated under vacuum (Kurucheve et al., 1997).The crude powder obtained after evaporation of the supernatant was kept in sealed glass vials and stored in refrigerator. A test solution (on dry wt/volume basis) was prepared for each extract by dissolving appropriate amount of powder in definite volume of water (Vitthalrao, 2004).

Testing of toxicity: The comparative toxicity of nine medicinal plant extracts (methanol powders) viz. A. paniculata leaves; A. graveolens leaves; A. indica fruit; $C$. fistula seeds; $C$. reflexa; D. falcata leaves; L. camara fruits and leaves; $M$. azedarach leaves and $V$. negundo stem were evaluated against 2 and $6 \mathrm{~d}$ old larvae of S.litura. Two concentrations, 5 and $10 \mathrm{mg} / \mathrm{ml}$ 
were prepared in water. Sandwiches $\left(\right.$ size $\left.3 \times 3 \mathrm{~cm}^{2}\right)$ were prepared from fresh leaf disc of Ricinus communis. Two leaf discs were used to make one sandwich. One $\mathrm{ml}$ of each of the concentrations of 5 and $10 \mathrm{mg} / \mathrm{ml}$ was spread thoroughly on the leaf disc with the help of a glass rod and then the other untreated leaf disc was sandwiched onto it. Control $(R$. communis) leaf sandwiches received only water. Three replications were maintained. The sandwiches were fed to 2days and 6days old larvae for 3days and observations were recorded on larval weight, larval weight gain and mortality parameters.

Statistical analysis: The experiment was conducted in completely randomized design (CRD) (Gomez and Gomez, 1984) and the data was analyzed by one way Analysis of Variance (ANOVA) following Snedecor and Cochran (1967) and the means were separated using, Duncan Multiple Range Test (DMRT) (Duncan, 1955) based SPSS16 computer programme.

\section{RESULTS AND DISCUSSION}

Effect on larval weight gain: All the medicinal plant methanol powders at both of the tested concentrations were effective in significantly reducing the weight gain of 2days and 6days old larvae of S. litura in comparison to control. The maximum reduction at $5 \mathrm{mg} / \mathrm{ml}$ concentration against 2 days old larvae was seen in D. falcata leaves $(98.58 \%)$ and A. indica fruit and $C$. reflexa stem (both $85.72 \%$ ) over control (larval weight gain at 3 days after feeding $=0.014 \mathrm{~g}$ ) followed by $L$. camara fruits $(58 \%)$, L. camara leaves (50\%), A. graveolens leaves $(42.86 \%), M$. azedarach leaves (35.72\%), A. paniculata stem (35.18\%), and C. fistula seeds and V. negundo stem (both 28.58\%) (Table1).
At $10 \mathrm{mg} / \mathrm{ml}$ concentration against 2 days old larvae of $S$. litura, the maximum reduction was caused by $C$. reflexa stem (98.58\%), C. fistula seeds and L. camara leaves (both $92.86 \%$ ) followed by A. paniculata stem and $V$. negundo stem (both 78.58\%), M. azedarach leaves $(71.43 \%)$ over control (larval weight gain at 3 days after feeding $=0.014 \mathrm{~g})$. A . indica fruit $(57.15 \%)$, D. falcata leaves and A. graveolens leaves (both 50\%) and L.camara fruit (21.43\%) also lowered weight gain over control. C. reflexa, A. indica, D. falcata and $L$. camara caused a negative weight gain, indicating loss in weight of the larvae at 3days after feeding (Table2). Maximum reduction in weight gain over control $(0.239 \mathrm{~g})$ against 6days old larvae of S.litura at $5 \mathrm{mg} / \mathrm{ml}$ conc. was exhibited by L. camara fruit $(99.43 \%)$ followed by $A$. graveolens leaves (76.16\%), M. azedarach leaves (55.65\%), C. fistula seeds (53.56\%), A. indica fruit and D. falcata leaves (both 48.96\%), L. camara leaves (37.66\%), A. paniculata stem $(36.51 \%), V$. negundo stem $(35.15 \%)$ and $C$. reflexa stem (9.2\%) (Table 3$)$.

At $10 \mathrm{mg} / \mathrm{ml}$ concentration the maximum reduction in weight gain over control $(0.239 \mathrm{~g})$ in 6days old larvae of S.litura was observed with L. camara fruit $(99.93 \%)$ and $A$. paniculata stem (89.54\%) followed by $A$. graveolens leaves (76.99\%), D. falcata leaves (74.99\%), C.reflexa stem (71.13\%), A.indica fruit (70.72\%), M. azedarach leaves (69.88\%), C. fistula $(66.11 \%)$, L. camara leaves $(61.09 \%)$ and V. negundo stem (59.42\%) (Table 4).

Toxicity: Five of the nine plant extracts viz., $A$. graveolens, A. indica, D. falcata, L. camara (both leaves and fruits) and $M$. azedarach at both the concentrations (5 and $10 \mathrm{mg} / \mathrm{ml}$ ) reflected varying

Table 1. Comparative effect of nine medicinal plants (methanol powder) on growth of 2 days old larvae of tobacco caterpillar, S. litura (Fab.) at $5 \mathrm{mg} / \mathrm{ml}$ concentration.

\begin{tabular}{lcc}
\hline Plant species scientific name & $\begin{array}{c}\text { Weight gain/larva } \\
\mathbf{S D A F}^{\#}(\mathbf{g})\end{array}$ & $\begin{array}{c}\text { Reduction in weight gain } \\
\text { over control }(\%)\end{array}$ \\
\hline Andrographis paniculata & $0.009 \pm 0.0005^{\mathrm{a}}$ & 35.18 \\
Anethum graveolens & $0.008 \pm 0.0005^{\mathrm{bc}}$ & 42.86 \\
Azadirachta indica & $0.002 \pm 0.003^{\mathrm{c}}$ & 85.72 \\
Cassia fistula & $0.01 \pm 0.001^{\mathrm{a}}$ & 28.58 \\
Cuscuta reflexa & $0.002 \pm 0.0007^{\mathrm{a}}$ & 85.72 \\
Dendropthoe falcata & $0.0002 \pm 0.001 \mathrm{a}$ & 98.58 \\
Lantana camara $(\mathrm{F})$ & $0.0009 \pm 0.001^{\mathrm{a}}$ & 93.58 \\
Lanana camara $(\mathrm{L})$ & $0.007 \pm 0.001^{\mathrm{a}}$ & 50.00 \\
Melia azedarach & $0.009 \pm 0.001^{\mathrm{bc}}$ & 35.72 \\
Vitex negundo & $0.01 \pm 0.0005^{\mathrm{ab}}$ & 28.58 \\
Control & $0.014 \pm 0.0005^{\mathrm{d}}$ & - \\
SEM $( \pm)$ & 0.0007 & - \\
CD at $1 \%$ & 0.003 & - \\
CD at 5\% & 0.002 & - \\
F value & $* *$ & - \\
\hline
\end{tabular}

Means followed by common letter do not differ significantly by Duncan Multiple Range Test ( $\mathrm{p}=0.05)$, Mean \pm SD of replicates; **=Highly significant; DAF= Days after feeding; $(\mathrm{F})=$ Fruits; $(\mathrm{L})=$ Leaves 
Table 2. Comparative effect of nine medicinal plants (methanol powder) on growth of 2 days old larvae of tobacco caterpillar, S. litura (Fab.) at $10 \mathrm{mg} / \mathrm{ml}$ concentration.

\begin{tabular}{lcc}
\hline Plant species scientific name & $\begin{array}{c}\text { Weight gain/larva } \\
\text { SDAF }^{\#}(\mathbf{g})\end{array}$ & $\begin{array}{c}\text { Reduction in weight gain } \\
\text { over control (\%) }\end{array}$ \\
\hline Andrographis paniculata & $0.003 \pm 0.001^{\mathrm{bc}}$ & 78.58 \\
Anethum graveolens & $0.007 \pm 0.001^{\mathrm{bc}}$ & 50 \\
Azadirachta indica & $-0.006 \pm 0.007^{\mathrm{a}}$ & 57.15 \\
Cassia fistula & $0.001 \pm 0.001^{\mathrm{c}}$ & 92.86 \\
Cuscuta reflexa & $-0.0002 \pm 0.0002^{\mathrm{a}}$ & 98.58 \\
Dendropthoe falcata & $-0.007 \pm 0.006^{\mathrm{a}}$ & 50 \\
Lantana camara $(\mathrm{F})$ & $-0.011 \pm 0.002^{\mathrm{a}}$ & 78.57 \\
Lanana camara $(\mathrm{L})$ & $0.001 \pm 0.0002^{\mathrm{b}}$ & 92.86 \\
Melia azedarach & $0.004 \pm 0.003^{\mathrm{c}}$ & 71.43 \\
Vitex negundo & $0.003 \pm 0.001^{\mathrm{c}}$ & 78.58 \\
Control & $0.014 \pm 0.0005^{\mathrm{d}}$ & - \\
SEM $( \pm)$ & 0.001 & - \\
CD at 1\% & 0.007 & - \\
CD at 5\% & 0.005 & - \\
F value & $* *$ & - \\
\hline
\end{tabular}

Means followed by common letter do not differ significantly by Duncan Multiple Range Test ( $\mathrm{p}=0.05)$; Mean $\pm \mathrm{SD}$ of replicates; $* *=$ Highly significant; $\mathrm{DAF}=$ Days after feeding; $(\mathrm{F})=$ Fruits; $(\mathrm{L})=$ Leaves

Table 3. Comparative effect of nine medicinal plants (methanol powder) on growth of 6 days old larvae of tobacco caterpillar, S. litura (Fab.) at $5 \mathrm{mg} / \mathrm{ml}$ concentration.

\begin{tabular}{lcc}
\hline Plant species scientific name & $\begin{array}{c}\text { Weight gain/larva } \\
\mathbf{3 D A F}^{\#}(\mathbf{g})\end{array}$ & $\begin{array}{c}\text { Reduction in weight } \\
\text { gain over control (\%) }\end{array}$ \\
\hline Andrographis paniculata & $0.512 \pm 0.01^{\mathrm{b}}$ & 36.41 \\
Anethum graveolens & $0.057 \pm 0.01^{\mathrm{a}}$ & 76.16 \\
Azadirachta indica & $0.122 \pm 0.01 \mathrm{ab}$ & 48.96 \\
Cassia fistula & $0.111 \pm 0.01^{\mathrm{ab}}$ & 53.56 \\
Cuscuta reflexa & $0.261 \pm 0.03^{\mathrm{c}}$ & 9.2 \\
Dendropthoe falcata & $0.122 \pm 0.01^{\mathrm{ab}}$ & 48.96 \\
Lantana camara $(\mathrm{F})$ & $0.137 \pm 0.04^{\mathrm{b}}$ & 99.43 \\
Lanana camara $(\mathrm{L})$ & $0.149 \pm 0.002^{\mathrm{b}}$ & 37.66 \\
Melia azedarach & $0.106 \pm 0.01 \mathrm{a}$ & 55.65 \\
Vitex negundo & $0.155 \pm 0.0 .02^{\mathrm{b}}$ & 35.15 \\
Control & $0.239 \pm 0.007^{\mathrm{b}}$ & - \\
SEM( \pm ) & 0.021 & - \\
CD at 1\% & 0.084 & - \\
CD at 5\% & 0.062 & - \\
F value & $* *$ & - \\
\hline
\end{tabular}

Means followed by common letter do not differ significantly by Duncan Multiple Range Test ( $\mathrm{p}=0.05$ ); Mean $\pm \mathrm{SD}$ of replicates; $* *=$ Highly significant; $\mathrm{DAF}=$ Days after feeding; $(\mathrm{F})=$ Fruits; $(\mathrm{L})=$ Leaves

degree of toxicity against $2 \mathrm{~d}$ old larvae of $S$. litura, the values being 16.66 and $50.00 \%, 50.00$ and $83.33 \%$, 50.00 and $83.33 \%, 16.66$ and $100 \%, 0.00$ and $16.66 \%$, 00.00 and $50.00 \%$ respectively. Only L. camara fruits proved toxic to 6 days old larvae of $S$. litura giving $100 \%$ mortality (Table 5).

It is evident from our observations that younger larvae are more susceptible to the effect of these medicinal plants whereas the older ones are quite resistant. They are able to withstand/tolerate the doses responsible for killing the younger larvae. S. litura is a generalist having a wide host range and tolerant/resistant to many insecticides (Srivastava and Joshi, 1965; Armes et al., 1997; Stanley et al., 2006; Bhargava et al., 2008;
Muthusamy et al., 2011). It is known to metabolize secondary plant metabolites (Zhau et al., 2011) and thereby it is capable of damaging even the toxic medicinal plants (Verma, 2006). Enough literature is available on the bioactivity (feeding deterrence, oviposition deterrence, repellence, toxicity, inhibition of growth and development) of neem tree, Azadirachta genus against various insect pests including S. litura (Schumutterer and Ascher, 1987; Ayyangar and Rao 1989; Kulkarni, 1999; Teik et al., 2005) where methanolic extract of $A$. indica and A. exelsa showed repellent activities at $0.02 \%$, inhibited feeding at $0.3 \%$ and decreased body length and weight and caused high mortality at a 
Table 4. Comparative effect of nine medicinal plants (methanol powder) on growth of 6 days old larvae of tobacco caterpillar, S. litura (Fab.) at $10 \mathrm{mg} / \mathrm{ml}$ concentration.

\begin{tabular}{lcc}
\hline Plant species scientific name & $\begin{array}{c}\text { Weight gain/larva } \\
\mathbf{3 D A F}^{\#}(\mathbf{g})\end{array}$ & $\begin{array}{c}\text { Reduction in weight } \\
\text { gain over control (\%) }\end{array}$ \\
\hline Andrographis paniculata & $0.025 \pm 0.002^{\mathrm{b}}$ & 89.54 \\
Anethum graveolens & $0.055 \pm 0.01^{\mathrm{bc}}$ & 76.99 \\
Azadirachta indica & $0.07 \pm 0.02^{\mathrm{cd}}$ & 70.72 \\
Cassia fistula & $0.081 \pm 0.006^{\mathrm{cd}}$ & 66.11 \\
Cuscuta reflexa & $0.069 \pm 0.01^{\mathrm{cd}}$ & 71.13 \\
Dendropthoe falcata & $0.06 \pm 0.01^{\mathrm{cd}}$ & 74.99 \\
Lantana camara (F) & $-0.17 \pm 0.004^{\mathrm{a}}$ & 99.93 \\
Lanana camara $(\mathrm{L})$ & $0.093 \pm 0.01^{\mathrm{cd}}$ & 61.09 \\
Melia azedarach & $0.072 \pm 0.009^{\mathrm{cd}}$ & 69.88 \\
Vitex negundo & $0.097 \pm 0.01^{\mathrm{d}}$ & 59.42 \\
Control & $0.239 \pm 0.007^{\mathrm{e}}$ & - \\
SEM( \pm ) & 0.012 & - \\
CD at 1\% & 0.049 & - \\
CD at 5\% & 0.036 & - \\
F value & & - \\
\hline
\end{tabular}

Means followed by common letter do not differ significantly by Duncan Multiple Range Test ( $\mathrm{p}=0.05)$; Mean \pm SD of replicates; **=Highly significant; DAF= Days after feeding; $(\mathrm{F})=$ Fruits; $(\mathrm{L})=$ Leaves

Table 5. Comparative effect of nine medicinal plants (methanol powder) on toxicity of 2 and 6 days old larvae of tobacco caterpillar, S. litura (Fab).

\begin{tabular}{|c|c|c|c|c|}
\hline \multirow[t]{3}{*}{ Plant species scientific name } & \multicolumn{2}{|c|}{ 2days } & \multicolumn{2}{|c|}{ 6days } \\
\hline & \multicolumn{4}{|c|}{ Abbotts corrected mortality (\%) } \\
\hline & $5 \mathrm{mg} / \mathrm{ml}$ & $10 \mathrm{mg} / \mathrm{ml}$ & $5 \mathrm{mg} / \mathrm{ml}$ & $10 \mathrm{mg} / \mathrm{ml}$ \\
\hline Andrographis paniculata & - & - & - & - \\
\hline Anethum graveolens & 16.66 & 50.00 & - & - \\
\hline Azadirachta indica & 50.00 & 83.33 & - & - \\
\hline Cassia fistula & - & - & - & - \\
\hline Cuscuta reflexa & - & - & - & - \\
\hline Dendropthoe falcata & 50.00 & 83.33 & - & - \\
\hline Lantana camara $(\mathrm{F})$ & 16.66 & 100 & - & 100 \\
\hline Lanana camara $(\mathrm{L})$ & - & 16.66 & - & - \\
\hline Melia azedarach & - & - & - & - \\
\hline Vitex negundo & - & 50 & - & - \\
\hline Control & - & - & - & - \\
\hline $\operatorname{SEM}( \pm)$ & - & - & - & - \\
\hline $\mathrm{CD}$ at $1 \%$ & - & - & & - \\
\hline $\mathrm{CD}$ at $5 \%$ & - & - & - & - \\
\hline F value & - & - & - & - \\
\hline
\end{tabular}

concentration of $0.5 \%$.

Significant insecticidal activity in methanolic extract of Artemisia nilagirica, Lantana wightiana and Synedrella nodiflora have been reported against fourth instar of $S$. litura (Rathi and Gopalakrishnan, 2004, 2006 and 2010). In a recent study, the methanolic/ethanolic extracts of Ocimum canum and Rhinacanthus nasutus and Clerodendron inerme and Cassia fistula have been reported insecticidal against third and fourth instar larvae of S. litura (Chauhan et al., 2011). The LC/LD50 values have been reported as 36.46 and $68.08 \mathrm{ppm}$ (O. canum and $R$. nasutus) against fourth instar and 3.846 and $1.703 \mathrm{ppm}$ ( $C$. inerme and $C$. fistula) against third instar larvae of $S$. litura.
Our investigation is in conformity with the findings of Pathrose et al. (2007) and Deepthy et al. (2010) where in the growth inhibiting activity and toxicity of methanol extract of Andrographis paniculata and Vitex negundo have been reported against larvae of S.litura.

\section{Conclusion}

All the medicinal plants tested showed reduction in larval weight gain over control showing their deleterious effect on growth of 2 days and 6 days old larvae of S.litura. The most prominent were D. falcata, A. indica, $C$. reflexa, $L$. camara (fruits) and $A$. graveolens. Significant reduction in larval weight resulted in death of the larvae, with highest mortality 
in L. camara (fruits), D. falcata and A. indica against smaller larvae while only L. camara (fruit) showed toxic effects to older larvae.

\section{ACKNOWLEDGEMENT}

The authors are thankful to Medicinal Plant Research and Development Centre (MRDC) of G. B. Pant University of Agriculture and Technology, Pantnagar for proving various plants for screening.

\section{REFERENCES}

Armes, N.J., Wightman, J.A., Jadhav, D.R. and Rao, G.V.R. (1997). Status of insecticide resistance in Spodoptera litura in Andhra Pradesh, India. Pesticide Science, 50:240-248.

Ayyangar, G.S.G. and Rao, P.J.(1989). Neem (Azadirachta indica A. Juss) extracts as larval repellents and ovipositional deterrents to Spodoptera litura (Fabr.).Indian journal of Entomology, 51(2): 121-124.

Bhargava, M.C., Choudhary, R.K. and Jain, P.C.(2008). Genetic engineering of plants for insect resistance.In: P.C. Jain and M.C Bhargava (eds.) Entomology: Novel Approaches. New India Publishing. New Delhi, India pp.133-144.

Celis, A., Mendoza, C., Pachón, M., Cardona, J., Delgado, W. Y. and Cuca, L. (2008). Plant extracts used as biocontrol with emphasis on Piperaceae family : A review.Una Revisión Agronomía Colombiana, 26:97106.

Chauhan, P., Shivakumar,M. S., Muthusamy, R. and Kumar, D.(2011). Larvicidal activity of solvent leaf extracts of Cassia fistula (Linn) and Clerodendron inerme (Gaertn) on the Spodoptera litura (Insecta: Noctuidae): A Potential Botanical Alternative. Journal of Ecobiotechnology, 3(7): 01-04.

Deepthy, K.B., Sheela, M.K., Sosamma, J., Estelitta, S. and Thomas, J.(2010). Insecticidal and growth inhibitory action of Vitex negundo Linn. against Asian army worm, Spodoptera litura Fab. Journal of Biopesticides, 3(1): $289-295$

Duncan, D.B.(1955). Multiple range and multiple F- tests.Biometrics, 11:1-42.

Gomez, K.A and Gomez, A.A.(1984).Statistical procedures for agricultural research. Second edition.John Wiley and Sons, New York.

Ibanez, S., Gallet, C and Despres, L.(2012).Plant insecticidal toxins in ecological networks.Toxins, 4: 228-243.

Kulkarni, N.(1999). Antifeedant and growth inhibitory effects of Azadirachta indica A. Juss, seeds against the larvae of Spodoptera litura (Fab.)(Noctuidae: Lepidoptera). National Academy of Science Letters, 22 $(1 / 2): 24-26$.

Kurucheve, V., Ezhilan, J.G and Jayaraj, J.(1997). Screening of higher plants for fungitoxicity against Rhizoctonia solani in vitro. Ind. Phytopathology, 50(2):235-241.

Muthusamy., Shivakumar., Karthi and Ramkumar. (2011).
Pesticide detoxifying mechanism in field population of Spodoptera litura (Lepidoptera: noctuidae) from South India. Egypt. Academic Journal of Biological Sciences, 3(1): 51- 57.

Pathrose, B., Srivastava, C. and Walia, S. (2007). Insect growth regulatory activity of Andrographis paniculata (Fa: Acanthaceae) extracts against tobacco caterpillar, Spodoptera litura. Indian Journal of Entomology, 69(1): $17-21$.

Rattan, R.S (2010). Mechanism of Action of Insecticidal Secondary Metabolites of Plant Origin. Crop Protection, 29(9): 913-920.

Rathi, J.M and Gopalakrishnan, S. (2010). Insecticidal activity of methanolic pooled fractions of Lantana wightiana Wall. Journal of Biopesticides, 3(1): 282 285.

Rathi, J.M and Gopalakrishnan, S.(2004).Insecticidal activity of Lantana wightiana (Wall.) on fourth instar larvae of Spodoptera litura (Fab.) (Lepidoptera: Noctuidae). Entomologia-crotica, 8(1/2):5-11.

Rathi, J.M. and Gopalakrishnan, S. (2006). Insecticidal activity of aerial parts of Synedrella nordiflora Gaertn (Compositae) on Spodoptera litura (Fab.). Journal of Central European Agriculture, 7(2):289-293.

Rembold, H. (1994). Secondary plant compounds in insect control with special reference to Azadirachtin. Advances in Invertebrate Reproduction, 3: 481-491.

Schumutterer, H. and Ascher K.R.S.(1987). Natural pesticides from the neem tree and other tropical plants. Proceedings of third International neem conference. Nairobi, Kenya.10-15July. GTZ, GmbH. Eschborn, Germany.pp:703.

Snedecor, G. W. and Cochran, W. G. (1967). Statistical methods. Oxford and IBH publishing Co., New Delhi, pp.593.

Srivastava, B.K and Joshi H.C.(1965). Occurrence of resistance to BHC in Prodenia litura Fabr. (Lepidoptera: Noctuidae). Indian Journal of Entomology, 27: 102-104.

Stanley, J., Chandrasekaran, S., Regupathy, A. and Jasmine, R.S. (2006). Baseline toxicity of emamectin and spinosad to Spodoptera litura. Annals of Plant Protection Sciences, 14: 346-349.

Teik, N.L., Mun, Y.P. and Hong, L.W.( 2005). Insecticidal effects of Azadirachta excelsa extract on Spodoptera litura (Lepidoptera: Noctuidae).Taiwanese Journal of Agricultural Chemistry and Food Science, 43(3):157161.

Verma, J.S. (2006). Insect pest problem in medicinal plants A review. Agricultural Reviews, 27:130-136.

Vitthalrao, B. K. (2004). Influence of juveniods on silkworm Bombyx mori (L.) .Thesis, Ph.D., Shivaji University, Kolhapur, Maharashtra, India.

Zhau, Y.Y., Luo, S.H.,Yi, T.S., Li, C.H.., Luo, Q., Hua, J. and Liu, S.H.(2011).Secondary metabolites from Glycine soja and their growth inhibitory effect against Spodoptera litura. Journal of Agricultural Food Chemistry, 59(11):604-10. 